\begin{tabular}{|c|c|c|c|c|c|c|}
\hline \multirow{4}{*}{ Impact Factor: } & ISRA (India) & $=3.117$ & SIS (USA) & $=0.912$ & ICV (Poland) & $=6.630$ \\
\hline & ISI (Dubai, UAE & $=0.829$ & РИНЦ (Russia) & $=0.156$ & PIF (India) & $=1.940$ \\
\hline & GIF (Australia) & $=0.564$ & ESJI (KZ) & $=8.716$ & IBI (India) & $=4.260$ \\
\hline & JIF & $=1.500$ & SJIF (Morocco) & $=5.667$ & OAJI (USA) & $=0.350$ \\
\hline
\end{tabular}

\begin{tabular}{|c|c|}
\hline $\begin{array}{l}\text { SOI: } \underline{1.1 / \mathrm{TA}} \\
\text { International Sc } \\
\text { Theoretical } \boldsymbol{\&} \mathbf{A}\end{array}$ & $\begin{array}{l}\text { S DOI: } 10.15863 / \mathrm{TAS} \\
\text { ientific Journal } \\
\text { pplied Science }\end{array}$ \\
\hline p-ISSN: 2308-4944 (print) & e-ISSN: 2409-0085 (online) \\
\hline Year: 2019 Issue: 05 & Volume: 73 \\
\hline Published: 24.05 .2019 & \\
\hline
\end{tabular}

SECTION 23. Agriculture. Agronomy. Equipment.
QR - Issue

QR - Article
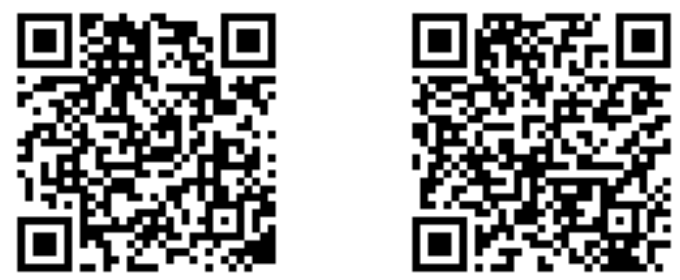

A.S. Umirbekova senior teacher, magister «Technology of food products, processing industries and biotechnology»

M.Kh. Dulaty Taraz State University

A.B. Sarshayeva teacher, magister

M.Kh. Dulaty Taraz State University

N. Maratkyzy

teacher, magister

M.Kh. Dulaty Taraz State University

\title{
PREPARATION OF THE NATURAL LIQUID RYE FERMENT WITHOUT YEAST
}

Abstract: It shows that the preparation of the natural liquid rye ferment without yeast have three stages. Food quality indicators and parameters have been defined, and a recipe for liquid rye ferment with addition of a pumpkin puree.

Key words: liquid rye sourdough, pumpkin puree.

Language: English

Citation: Umirbekova, A. S., Sarshayeva, A. B., \& Maratkyzy, N. (2019). Preparation of the natural liquid rye ferment without yeast. ISJ Theoretical \& Applied Science, 05 (73), 249-253.

Soi: http://s-o-i.org/1.1/TAS-05-73-35 Doi: crossef https://dx.doi.org/10.15863/TAS.2019.05.73.35

\section{INTRODUCTION}

Baking bread without sourdough is known from early times. However, nowadays it is hardly used in Kazakhstan. Its different usefulness of alimal natural, that is organic ychildren is alimal valuable human body, natural and mineral substances, vitamins, enzymes, fibers, natural and enriches pettinen biostimulation [1].

The flow rate of biotechnological processes, rye, rye-wheat, mainly for raw materials, basic ndary nandarani the quality of the mixture, i.e. depending on the properties of rye aymalina.Currently, bold, dry and liquid alimardani in the preparation of science - based sketches are used.Wide application of liquid fermented rye in obtaining finished products is of high quality.Rye alumaline quality can be determined by many factors, but most often in the composition of the nutrient medium, i.e., determines the opening of raw by growing the microflora.

The basic rules governing the composition of the nutrient mixture:

1. The direction of change of the process parameters (temperature, humidity, aeration, etc.)
2. Positive impact on the discovery of microflora, carbohydrates and other components in the composition of matter (minerals, nitrogen, vitamins, natural vegetable mixture, you can add [2].

1 gramm of flour contains millions of microorganisms. The qualitative composition of microorganisms, fungi, bacteria, actinomycetes and other micro-organisms, there are species. But in the case of a low level. Flour humidity is

$15 \%$ lower than in the case of not only active microorganisms, but also semi-finished products in the production of bakery humidity of $40-50 \%$ goarland, the conditions for the development of all types of microorganisms.

Flour, amino acids, vitamins solution for microorganisms later tested for allergic reactions and the settings will be available. From this moment begins the struggle for the possession of competitive micro-organisms among the various habitats. In this case, can maintain the activity of microorganisms adapted to life not better than others. The dough bambergen lactic acid bacteria is the best conditions. And they multiply faster than others. In 


\begin{tabular}{|c|c|c|c|c|c|c|}
\hline \multirow{4}{*}{ Impact Factor: } & ISRA (India) & $=3.117$ & SIS (USA) & $=0.912$ & ICV (Poland) & $=6.630$ \\
\hline & ISI (Dubai, UAI & $=0.829$ & РИНЦ (Russia & $=0.156$ & PIF (India) & $=1.940$ \\
\hline & GIF (Australia) & $=0.564$ & ESJI (KZ) & $=8.716$ & IBI (India) & $=4.260$ \\
\hline & JIF & $=1.500$ & SJIF (Morocco & $=5.667$ & OAJI (USA) & $=0.350$ \\
\hline
\end{tabular}

addition to lactic acid, which reduces and microorganisms. First, the most important alkaline (delocalise) microorganisms (bacteria and others) wanting a neutral environment, then microorganisms (E. Coli's bacteria group) dies.Next, most importantly bacteria the acidity in acid (butyric acid, acetic acid), stop the activity.Bacteria, different types of yeast that wants the highest isyndicate environment (sacharomyces and saharomiceta), growth is only possible in aerobic conditions and other fungi.And Saccharomyces is anaerobic. It appears ottext flour raw material that can develop. The result of the cultivation on high acidity (esimal, dough) yeast, which remain to grow in anaerobic conditions and lactic acid. In this regard, asytelin lactic acid bacteria intad alcohol, lactic acid and oxygen of extraneous microorganisms are not allowed to participate in development. In this regard, lactic acid bacteria and yeast is the synergists [3].

Active life yeast of lactic acid bacteria affecting capital liquid nitrogen and carbon, which are the main source of sourdoughsubstructuring nutrition, vitamins, stimulants, farming and minerals requires. The main monosaccharides and disaccharides are consumed. Liquid nutritional mixture of flour and water is the main source of fermented milk living in certain sizes.

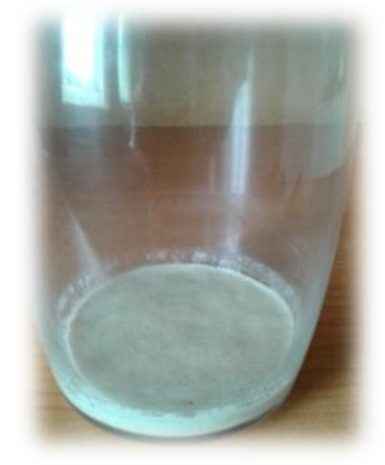

Picture - a. the first phase of sourdough

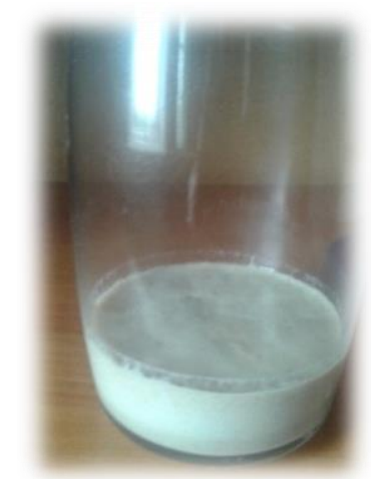

Picture- b. the second phase of sourdough
Liquid nutritional mixture of coal and water and increases the absorption of sugar in alumaline to increase size advised to add mashed pumpkin rye.

Light texture is instantly absorbed, composed of a large amount of carbohydrates and various features of the chemical composition of water in the presence of the size of the pumpkin, sugar, average amount, and vitamin $\mathrm{C}$, pectin and relatively high dimensionality of minerals, especially iron and potassium in large quantities. And pumpkin, pumpkin and meat are carotene yellow color, which is very rich, its useful properties were determined by conducting the heat treatment in its goaltimate.

In the course of the study, independently Asites, alicyn liquid natural shymalan rye, from a mixture of flour and water only was prepared. In the study, humidity $75 \% 200 \mathrm{~g}$ water through the flour, prepared the calculation of the amount of Alimandi.

The preparation of sourdoughwas divided into three phases. Flour without impurities of the feed water and control developed just a sample. After each phase is defined Alimandi quality indicators. Three manifestations of the General alimardani made in the phase of the 1 st figure. Only flour and water are added into the first phase pickle for 24 hours at $28^{\circ} \mathrm{C}$ at a temperature (picture - a,).

Picture 1. Sourdoughis made in three phases

In this phase of sourdough, its surface surface blisters, and the smell becomes bad. It explains that the microorganisms in its composition evolvement. Fermented milk acidity reaches 6 degrees. A mixture of flour and water equal to the weight sour, living in these nutrient germented milk in the second phase, that is picled of $28^{\circ} \mathrm{C} 12$ hours at a temperature. (picture -b).

As a result, the acidity of sourdoughreaches 9 degrees. The smell gradually turns to normal. The taste is a bit sour and the appearance becomes good.
In the third phase, add the nutritional additive equal to the weight of the starch and pickle at $28^{\circ} \mathrm{C}$ for 6 hours (picture-c).

As a result, the acidity of sourdoughreached 11 degrees. In the third phase, the taste and smell of a ready-made fermented milk appeared. When the desired sourness of sourdoughis reached and the taste and smell are characteristic to it, the multiplication cycle stops.

The high quality of preparation and quality indicators are shown in Table 1. 


\begin{tabular}{|c|c|c|c|c|c|c|}
\hline \multirow{4}{*}{ Impact Factor: } & ISRA (India) & $=3.117$ & SIS (USA) & $=0.912$ & ICV (Poland) & $=6.630$ \\
\hline & ISI (Dubai, UAE & $=0.829$ & РИНЦ (Russia & $=0.156$ & PIF (India) & $=1.940$ \\
\hline & GIF (Australia) & $=0.564$ & ESJI (KZ) & $=8.716$ & IBI (India) & $=4.260$ \\
\hline & JIF & $=1.500$ & SJIF (Morocce & $=5.667$ & OAJI (USA) & $=0.350$ \\
\hline
\end{tabular}

Table 1. Quality and performance indicators of the liquid wheat

\begin{tabular}{|l|l|l|l|}
\hline Indicators & \multicolumn{3}{|c|}{$\begin{array}{l}\text { Multiplication cycle of } \\
\text { products in phasal yield }\end{array}$} \\
\hline Composition & I & II & III \\
\hline Black rye flour, g & 50 & 50 & 100 \\
\hline Water, g & 85 & 85 & 170 \\
\hline Technological part & & & \\
\hline Total weight of fermented milk, g $^{\prime}$ & 135 & 135 & 270 \\
\hline Temperature, $^{\circ} \mathrm{C}$ & 28 & 28 & 28 \\
\hline Moisture, $\%$ & 75 & 75 & 75 \\
\hline Acidity, ${ }^{\circ} \mathrm{C}$ & 6 & 9 & 11 \\
\hline Duration of sourdough, hours & 24 & 12 & 6 \\
\hline
\end{tabular}

When the acidity reaches 9-13 degrees, liquid black rye's sourdough is put to the fridge for two days to supress the sourdough level. Only then it can be used. Ready-made sourdough's preserving time limit is 30 days. If it needed to be preserved more, nutrition should be added. As a nutrition we mean the equal weight of flour and water. Before adding to the sourdough the nutrition should be warmed up. After nutrition is added the sourdough needed to pickle 2.5 - 3 hours at $28-30{ }^{\circ} \mathrm{C}$, then it can be put into the refridgerator.

After sourdough is put into the refridgerator, microorganisms of sourdough are dead for some time, and the acidity of sourdough becomes normal. If there is a right condition to the sourdough, its microorganisms evolve again.

If the temperature for sourdough is high, microorganisms develop with high rate and therefore the acidity becomes too high. It can lead to the inapplicability. Invalid sourdough is forbidden to use. Therefore, it is preserved in the fridge.

If the acidity of sourdough is not reached the right condition, mixed dough and baked bread would be of a bad quality.

Organoleptical and phisical-and-chemical indicators of the sourdough are shown in the $2^{\text {nd }}$ table.

Table 2. Organoleptical and phisical-and-chemical indicators of the sourdough

\begin{tabular}{|c|c|}
\hline Indicators & Liquid rye sourdough \\
\hline \multicolumn{2}{|c|}{ Organoleptical indicators } \\
\hline Color & Grey \\
\hline Taste & Has its own sour taste without any additional taste \\
\hline Smell & Has its own smell without any additional smell \\
\hline \multicolumn{2}{|c|}{ Phisical-and-chemical indicators } \\
\hline Moisture, \% & 75 \\
\hline Acidity, ${ }^{\circ} \mathrm{C}$ & 11 \\
\hline
\end{tabular}

With the $75 \%$ moisture of liquid rye sourdough to make $200 \mathrm{~g}$ dough is made its composition. To make this mixed dough we take ready-made product which was stored in the refrisgerator. First of all, it is taken from the fridge and if it is expected to warm by the room temperature, it takes long time. Therefore, it should be put into the water with $40^{\circ} \mathrm{C}$ temperature for
30-60 minutes till it is ready. To make it faster we need to add warm water every 5-10 minutes.

To find the quality indicator of pumpkin puree to liquid sourdough we add to flour with the $10 \%, 20 \%$, $30 \%$ and $40 \%$ consistency. Sourdough composition and its quality indicator with pumpkin puree are shown in the $3^{\text {rd }}$ table. 


\begin{tabular}{|c|c|c|c|c|c|c|}
\hline \multirow{4}{*}{ Impact Factor: } & ISRA (India) & $=3.117$ & SIS (USA) & $=0.912$ & ICV (Poland) & $=6.630$ \\
\hline & ISI (Dubai, UAE & $=0.829$ & РИНЦ (Russia & $=0.156$ & PIF (India) & $=1.940$ \\
\hline & GIF (Australia) & $=0.564$ & ESJI (KZ) & $=8.716$ & IBI (India) & $=4.260$ \\
\hline & JIF & $=1.500$ & SJIF (Morocce & $=5.667$ & OAJI (USA) & $=0.350$ \\
\hline
\end{tabular}

Table 3. Sourdough composition and its quality indicator with pumpkin puree

\begin{tabular}{|c|c|c|c|c|c|}
\hline Indicators & Traditional & The qu & of pum & tree sho & percentage \\
\hline Composition & & $10 \%$ & $20 \%$ & $30 \%$ & $40 \%$ \\
\hline 1 & 2 & 3 & 4 & 5 & 6 \\
\hline Sourdough, $g$ & 100 & 100 & 100 & 100 & 100 \\
\hline Nutritional supplement, $\mathrm{g}$ & 100 & 100 & 100 & 100 & 100 \\
\hline Rye flour, $\mathrm{g}$ & 28,4 & 25,56 & 22,72 & 19,88 & 17,04 \\
\hline Pumpkin puree, $\mathrm{g}$ & - & 2,84 & 5,68 & 8,52 & 11,36 \\
\hline Water, g & 71,6 & 71,6 & 71,6 & 71,6 & 71,6 \\
\hline Technological part & & & & & \\
\hline Temperature, ${ }^{\circ} \mathrm{C}$ & 35 & 35 & 35 & 35 & 35 \\
\hline Moisture, \% & 75 & 77 & 79 & 82 & 85 \\
\hline Acidity, ${ }^{\circ} \mathrm{C}$ & 12 & 12 & 12 & 12 & 12 \\
\hline Power of rising & 35 & 35 & 30 & 25 & 25 \\
\hline Duration of fermenting, hours & 3,5 & 3,5 & 3,5 & 3 & 3 \\
\hline
\end{tabular}

\section{Conclusion}

At the time of testing, the moisture content was increased by $85 \%$ and the viscosity decreased and the production was accelerated. As a result, the gastrointestinal tract of $75 \%$ of the body has been severely degraded. As a result, pumpkin urea remained uniform, without changing the acidity of the acids and accelerated its lifting forces, and reduced the amount of fermenting.

The results shown by organic and physical-andchemical indicators have the right consistency if to this is added $30-40 \%$ of pumpkin puree.

As the experiment has shown, $10 \%$ of pumpkin puree added to the liquid rye did not show any differences, $20 \%$ of pumpkin puree added to the liquid rye reduced to the duration of fermenting for 5 minutes, $30 \%-40 \%$ of pumpkin puree added to the liquid rye reduced to the duration of fermenting for 30 minutes. $10 \%$ of pumpkin puree added to the liquid rye showed the difference only in the moisture. It was risen to $77 \%$.As a result, it was shown that adding pumpkin puree to the liquid rye sourdough had no any negative impact.

Adding an increased dose of the mixture with carbon and microorganisms involved in the fermentation process, they suppress the growth of milk fermentation.

The smell of the sourdough becomes special, or rather smells like the aroma of fruit. Thus it was determined that the nutritional mixture added to the ferment activates the symbiotic viability of the ferment microorganisms. In the composition of the nutritional mixture is added the pumpkin puree, first of all it enriches its composition with hydrocarbons and other vitamins.

Estimating the baking properties of rye flour, we can say that it is optimal for the growth of symbiotic growth of sour-milk bacteria in a liquid rye ferment, and it was also proved that when preparing the starter the parameters were optimal for the ferment microorganisms.

\section{References:}

1. Auerman, L. Y. (2002). Technology of bakery production: Textbook. 9 thed.; Revised. and ext.
/ Under common. L.I.Puchkova. - St. Petersburg. Profession. 


\begin{tabular}{|c|c|c|c|c|c|c|}
\hline \multirow{4}{*}{ Impact Factor: } & ISRA (India) & $=3.117$ & SIS (USA) & $=0.912$ & ICV (Poland) & $=6.630$ \\
\hline & ISI (Dubai, UAE & $=0.829$ & РИНЦ (Russia & $=0.156$ & PIF (India) & $=1.940$ \\
\hline & GIF (Australia) & $=0.564$ & ESJI (KZ) & $=8.716$ & IBI (India) & $=4.260$ \\
\hline & JIF & $=1.500$ & SJIF (Morocce & $=5.667$ & OAJI (USA) & $=0.350$ \\
\hline
\end{tabular}

2. Pashchenko, L. P. (2002). Biotechnological foundations of bakery products production. Moscow "KOLOS".

3. Matveeva, I. V., \& Belyavskaya, I. G. (2001). Biotechnological foundations of bread preparation: Textbook. Manual for universities Moscow: DeLi print.

4. Shapiro, L. M., \& Hatcher, E. A. (1978). Process for the preparation of a hydrolyzed product from whole gran//U.S. patent documents// oct. 13, 1978. - No.: 951,076

5. Raymond, N. J., \& Hatcher, E. A. (1978). Process for the preparation of a hydrolyzed product from whole grain and such a product $\backslash$ U.S. Patent documents.- Continuation of ser. No. 951,076, oct. 13, 1978, pat.No. 4,282,319.

6. (n.d.). Bread making. Improving quality. /Edited by Stanley P.Cauvain, CRC Press ,Boca Raton (Eds.). (p.580). Boston New York Washington, DC, Woodhead publishing limited, Cambridge England.
7. Davison, P. M. (1990). Antimicrobial agents/ P.M.Davison, V.K.Juneja// Fooad additives/ Ens.Branen,A.L., Davison ,P.M.,Salminen,S,$\mathrm{NY}^{\wedge}$ Marcel Dekker,Inc.

8. Kuznetsova, L. I., Usova, L. V., Gavrilova, T. A., Savkin, O. A., \& Ternovskoy, G. V. (2015). Secondary processing of bakery products in the technology of production of rye bread on a thick leaven. Bakery of Russia, No.5, pp.18-20.

9. Puchkova, L. I., Polandova, R. D., \& Matveeva, I. V. (2005). Technology of bread, confectionery and pasta. Part 1. Technology of bread. [Text] / (p.559). St. Petersburg: GIORD.

10. Anikeeva, N. V. (2011). Production of bread using chick pea flour and protein isolate from chickpea seeds [Text]. Storage and processing of grain, No. 7 (145), pp. 59-62.

11. Kuznetsova, L. I., Savkina, O. A., Pavlovskaya, E. N., Lokachuk, I. N., \& Ternovskoy, G. V. (2014). Perfection of the lapping cycle of a thick rye ferment. Breadbaking of Russia, №4. 